\title{
ARGILOMINERAIS DA BACIA DE TAUBATÉ, SP
}

\author{
M.Brandt Neto ${ }^{1}$ \\ C.Riccomini ${ }^{2,3}$ \\ A.M.Coimbra ${ }^{2,3}$ \\ S.L.F. de Matos ${ }^{4,5}$
}

\section{INTRODUÇÃO}

O preenchimento sedimentar continental terciário da Bacia de Taubaté é atualmente subdividido em duas seqüências (RICCOMINI, 1989). A inferior, Grupo Taubaté, de idade paleogênica (Oligoceno), corresponde ao preenchimento sintectônico, compreendendo um sistema de leques aluviais associados à planície aluvial de rios entrelaçados (braided), basal e lateral na bacia (Formação Resende), um sistema lacustre, mais propriamente caracterizável como playa-lake (Formação Tremembé), e um sistema fluvial meandrante (Formação São Paulo), este de ocorrência restrita à porção sudoeste da bacia. A seqüência superior, separada da anterior por discordância angular, corresponde a outro sistema fluvial meadrante, de idade neogênica, bem desenvolvido na porção central da bacia, sendo denominada Formação Pindamonhangaba.

Os argilominerais presentes nas diferentes unidades sedimentares da Bacia de Taubaté ainda não foram objeto de estudos sistemáticos, embora alguns depósitos estejam sendo explorados economicamente já há algumas décádas (RICCOMINI, 1989). Os estudos realizados são de caráter mais local, notadamente voltados às ocorrências das denominadas

\footnotetext{
UNESP, São José do Rio Preto, SP.

2 Departamento de Paleontologia e Estratigrafia, Instituto de Geociências/USP, São Paulo.

${ }^{3}$ Bolsista do CNPq.

${ }^{4}$ Bolsista da CAPES

${ }^{5}$ Pós-Graduação, Instituto de Geociências/USP, São Paulo.
} 
argilas "bentoníticas" da porção central dessa bacia.

\section{OBJETIVOS E MÉTODOS}

A análise de argilominerais no presente estudo compreendeu a caracterização mineralógica por difração de raios X, somada à análise por microscopia eletrônica de varredura (MEV), esta possibilitando a visualização das formas, dimensões e, principalmente, a disposição e relações dos argilominerais com outras partículas dos sedimentos. Dessa forma puderam-se obter indicações mais seguras quanto aos processos físico-químicos atuantes previamente e durante a sedimentação, e em termos paleoambientais (BRANDT NETO et al., 1987) e paleotectônicos.

\section{RESULTADOS OBTIDOS}

Os argilominerais identificados correspondem aos grupos da esmectita, da clorita, illita, caulinita, além de outros minerais; suas morfologias e formas de ocorrência são descritas em relação às diferentes unidades em que foram constatadas suas presenças.

As esmectitas ocorrem fundamentalmente sob a forma de finas placas de bordos arqueados e, mais raramente, como flocos com arranjos lembrando "pé-de-alface", com cristais de calcita intersticiais.

Esmectitas como finas placas estão presentes e constituem-se no argilomineral essencial na matriz lamítica não alterada dos lamitos arenosos e arenitos da Formação Resende e nas argilas esverdeadas maciças e folhelhos castanho-escuros da Formação Tremembé.

As finas placas encurvadas das esmectitas, presentes essencialmente em fácies sedimentares argilosas, de difícil percolação por soluções intraestratais, devem ser oriundas do material detrítico mais fino, fornecido à bacia durante a sedimentação.

Ao contrário, as esmectitas associadas à calcita, ou seja, aos calcretes da Formação Resende, são provavelmente diagenéticas, sobretudo pelas suas delicadas formas, não sugestivas de retrabalhamento mecânico. Sua gênese deve estar ligada à liberação da silica de grãos de quartzo, submetidos a ataque superficial por águas ácidas, carbonatadas, ascendentes por capilaridade (evapotranspiração>precipitação), reagindo com a esmectita 
detrítica e formando arranjo autígeno envolvendo os grãos de quartzo. Com o equilíbrio, o meio torna-se menos ácido, conduzindo à cristalização de calcita intersticial.

A clorita ocorre associada com a esmectita nas argilas esverdeadas da Formação Tremembé e, mais raramente, nos lamitos da Formação Resende. Apresenta cristais individuais com formato de pequenos "repolhos" salpicados na massa esmectítica. Trata-se, sem dúvida, de clorita diagenética, pois eventual transporte teria destruído mecanicamente as delicadas formas observadas.

A ocorrência de illita pôde ser assinalada com certo grau de segurança apenas nas argilas verdes maciças da Formação Tremembé, onde constituem prismas hexagonais associados à clorita, ambas certamente diagenéticas.

A caulinita ocorre sob a forma de pequenos flocos planos de bordos angulosos, como placas pseudohexagonais de tamanho reduzido, formando, no conjunto, massas irregulares, e ainda cristais de maiores dimensōes, com contorno hexagonal conspícuo e justapostos de forma a constituirem agregados que se assemelham à sanfona, hábito este também denominado de vermiforme (SCHOLLE, 1979). As duas primeiras formas, pelas suas dimensões reduzidas e baixo grau de cristalinidade, são interpretadas como alogênicas, ao passo que as "sanfonadas", de maiores dimensões e maior grau de cristalinidade, seriam diagenéticas.

A caulinita detrítica está presente em praticamente todas as unidades sedimentares. Ela se apresenta freqüentemente associada com a esmectita detrítica, ou até com a clorita.

Caulinita diagenética, é localmente, o argilomineral principal das formações São Paulo e Pindamonhangaba. Um excelente exemplo são as argilas brancas situadas abaixo do linhito descrito por SUGUIO et al. (1985) em Guararema.

Halloisita tem, aparentemente, ocorrência restrita em arenitos grossos, arcoseanos, conglomeráticos, que ocorrem intercalados com as argilas verdes maciças de Formação Tremembé. Apresenta hábito prismático alongado, tendendo a acicular, com arranjo irregular entre os cristais, de provável origem diagenética. Tal diagênese é resultante, provavelmente, de produto de decomposição de feldspatos abundantes nessa fácies, ou ainda de recristalização de caulinita.

\section{CONCLUSÕES}


Os leques aluviais com lamitos da Formação Resende são caracterizados pela presença de argilominerais detríticos do grupo das esmectitas. Tal associação é sugestiva de área-fonte mal drenada, em condições de clima semi-árido, o que é corroborado pela presença de depósitos tipo caliche associados aos lamitos. A sedimentação processou-se principalmente sob a forma de corridas de lama, associadas aos desnivelamentos de origem tectônica existentes àquela época.

Para a Formação Tremembé a bacia apresentava dimensões suficientemente largas para que se desenvolvessem, em condições mais distais, provavelmente associadas a etapas de predominância de calmaria tectônica, espessura considerável de sedimentos lacustres. Nestes depósitos, embora o registro predominante seja ainda de esmectitas detríticas, é freqüente a ocorrência de cloritas neoformadas e sulfetos (piritas?) framboidais. Esta associação já seria mais própria de condições redutoras na sedimentação, o que no presente caso é suportado pela presença de matéria orgânica abundante, inclusive folhelhos negros, dessa fase. Reativações tectônicas episódicas durante a fase lacustre têm seu registro nas intercalações conglomeráticas com esmectita e halloisita detríticas, indicando área-fonte nos granitos e gnaisses do embasamento adjacente.

Na fase final do Grupo Tremembé, a bacia apresenta o desenvolvimento de um sistema fluvial essencialmente meandrante (Formação São Paulo), sob condições de maior aeração e portanto mais oxidantes e talvez mais úmidas, ora com a deposição de caulinitas detríticas, ora com registro de caulinitas neoformadas sanfonadas, provavelmente diagenéticas. Já desvinculada da história terciária mais antiga, provavelmente no final do Terciário ou talvez início do Quaternário, a bacia foi recoberta discordantemente por sedimentos fluviais meandrantes (Formação Pindamonhangaba), onde a caulinita neoformada é o argilomineral essencial.

\section{REFERÊNCIAS BIBLIOGRAFICAS}

BRANDT NETO, M.; BARELLI, N.; BARCHA, S.F.; COIMBRA, A.M. (1987) Ocorrências de analcima em sedimentos da Formação Adamantina em Macedônia (Estado de São Paulo), uma evidência de hidrotermalismo no Grupo Bauru. In: SIMPÓSIO REGIONAL DE GEOLOGIA, 6., Rio Claro. Atas. Rio Claro, SBG. V.1, p.113-121.

RICCOMINI, C. (1989) O Rift Continental do Sudeste do Brasil. São Paulo. 256p. (Tese de 
Doutorado - Instituto de Geociências/USP).

SCHOLLE, P.A. (1979) A collor illustrated guide to constituents, cements, and porosities of sandstones and associated rocks. AAPG Memoir, (28), 201p.

SUGUIO, K.; VESPUCCI, J.B.O.; LIMA, M.R. (1985) Paleoambientes deposicional e diagenético do linhito da Formação Caçapava, Terciário da Bacia de Taubaté, SP. Geociências, (4):23-33. 